\title{
DNA Probes
}

National Cancer Institute

\section{Source}

National Cancer Institute. DNA Probes. NCI Thesaurus. Code C451.

A piece of DNA that has been labeled, usually radioactively or with a fluorescent dye, which is used in hybridization studies. Applications include Northern and Southern blots, in situ hybridization techniques, and diagnostic tests. DNA probes can be highly specific or degenerate. 